\title{
3 From Temporary Work in Agriculture to Irregular Status in Domestic Service: The Transition and Experiences of Senegalese Migrant Women in Spain
}

\author{
Aly Tandian ${ }^{1}$ and Sylvia I. Bergh ${ }^{2}$
}

\begin{abstract}
$^{3}$
Amid increasing irregular flows of Senegalese migrants to Spanish territories, the two countries entered into a bilateral agreement in 2007 for a temporary work scheme that ultimately saw the migration of more than 700 Senegalese women for work in the agricultural sector in Spain. Due to a number of factors, including weaknesses in the recruitment process on the sending side and the nature of the work on the receiving side, many of the women subsequently abandoned their posts in search of domestic work or jobs in personal services in Spanish cities, thus transitioning to irregular status. Using data collected from 525 of these Senegalese migrant women, this chapter examines how they came to form this unintended cohort of unauthorized migrants and their experiences as they strive to live, work, and access various social rights in the context of the current Spanish labour market and economic crisis. Some measures are suggested to strengthen the management of future temporary work schemes and protect Senegalese women migrants in Spain.
\end{abstract}

Keywords: Agriculture, domestic work, gender, labour market, migration, Senegal, social justice, Spain, women.

\subsection{Introduction}

This chapter focuses on Senegalese women migrants' economic and social situation (including access to social protection) in Spain, largely as presented through their own eyes. These women first came to Spain in 2007 as part of a temporary agricultural work scheme which they abandoned for various reasons, and then ended up as migrants with irregular immigration sta-

1 Aly Tandian is Director of the 'Groupe d'Etudes et de Recherches sur les Migrations \& Faits de Sociétés', Université Gaston Berger de Saint-Louis, Senegal.

2 Sylvia I. Bergh is Senior Lecturer in Development Management and Governance at the International Institute of Social Studies, Erasmus University Rotterdam, The Netherlands.

3 We would like to thank the Groupe d'Etudes et de Recherches sur les Migrations \&o Faits de Sociétés (GERM) \& Faits de Sociétés, the two anonymous reviewers, Giulia Sinatti, Thanh-Dam Truong, and Des Gasper for their valuable support and comments. We would also like to thank Marianne Dobner and Simone Tappert for sharing their unpublished work with us. tus $^{4}$ in a variety of occupations in the care sector, especially in domestic work.

So far, research on Senegalese migration has focused on three main areas. First, Senegalese international (and especially intercontinental) migration is the object of a large corpus of research, though this has traditionally been conducted from a strictly global economic angle, with an emphasis on men and therefore without specifying the situation of women (Garreta Bochaca 200I). ${ }^{5}$ Second, research using the transnational approach in particular has focused significantly on non-economic aspects of this migration.

4 Following the United Nations Educational, Scientific and Cultural Organization (UNESCO 2008: 15), "persons with irregular immigration status" refers to persons "entering, travelling through or residing in a country without the necessary documents or permits".

5 See also the Migrations between Africa and Europe (MAFE) research project publications on Senegal, including Lessault and Mezger (2010) and González-Ferrer and Graus (20I2). See <http://www.mafeproject. $\mathrm{com} />$. For an overview of Senegalese migration flows, see Wabgou (2008). 
However, while transnationality is now one of the most popular concepts in migration research, the processes of immigrants' dynamics in destination countries such as their moves across sectors have not been the focus of much scholarly attention (Van Nieuwenhuyze 2009: 16, 30). Third, research covering the migration of women to Spain and other European countries is widespread (e.g. Gutiérrez-Rodríguez 20IO; Lutz 20II). Yet despite feminization trends being on the rise in Senegalese migration and women having entered the debate on labour migration management (e.g. seasonal migration schemes), most academic research treats them as wives or as independent, self-employed merchants (commerce de valise) (e.g. Rosander 2005; Babou 2008; Blanchard 20I2). Research focusing on female migration to Spain or Europe has further been limited to issues involving migrant remittances to Senegal and family reunification, and not much has been written about their economic and social rights (the right to decent work, the right to adequate housing, the right to social protection, the right to adequate health care, among others; Apap 200I; Sow 2006; Coulibaly-Tandian 2008). Similarly, the process of becoming a migrant with irregular status' after having entered a country legally has rarely been the focus of research.

This chapter therefore contributes to our knowledge by focusing on the independent migration of women as labour migrants, which can be empowering for them, but also on the patterns of exclusion that they face in the country of immigration (Spain, in this case). The main research question to be addressed here is: why and how do initially legal temporary women labour migrants (in the agricultural sector) acquire 'irregular' status in Spain, and how do they fare as such in the domestic work sector?

Migrants with 'irregular status' or 'undocumented' or even 'illegal' migrants, as they are also often referred to, have become increasingly a pressing policy issue at the core of the migration debate, as undocumented migrants by definition challenge the system, break laws and rules, and compete with legal migrants and citizens for job opportunities, while living at the core of many European societies and performing much-needed services (Van Nieuwenhuyze 2009: 36-37).

There is thus an urgent need for a comprehensive understanding of the integration of Senegalese women migrants in the (formal and informal) labour market, with an emphasis on social protection for workers in sectors such as agriculture and domestic services where individual migrants appear to be ex- posed to health risks and social costs such as poisoning, food shortages, low wages, overwork, etc. According to the International Labour Organization (ILO), these issues are crucial to the fundamental rights of migrants, in particular with reference to the Decent Work Agenda. ${ }^{6}$

The findings presented here are also of considerable policy relevance, given that the EU and its member states are considering increasing temporary/seasonal labour schemes in the agricultural sector. Policymakers are thus invited to learn from the Senegal experience how schemes and access to rights can be improved.

The rest of the chapter is structured as follows. The next section will discuss the research methodology. This is followed by a brief review of Senegalese migration to the EU and Spain and its legal framework, setting the context for the research findings. These are presented in two main parts: one dealing with the temporary agricultural work migration scheme, and another, more substantive one on the process of becoming irregular migrants employed in the domestic work sector in Spain. This is followed by a discussion of the legal and social implications of migrant workers' 'invisibility'. The chapter ends with a brief assessment of migrant workers' attempts at claiming social protection and some conclusions focusing on the implications of the findings for migration policy.

\subsection{Methodology}

This chapter is based on a research project that focused on the social protection of Senegalese women migrants operating in agricultural activities and personal care/domestic work in Spain. ${ }^{7}$ Given the main research question mentioned above, the methodology was designed to elicit insights from the women migrants themselves as much as possible. A survey was conducted among Senegalese women who were part of a temporary migration scheme set up by the governments of Senegal and Spain in the agricultural sector, specifically strawberry picking, as well as migrants who had already arrived in Spain earlier. The majority of women were workers with an irregular status who had become such after abandoning agricultural activities to work as domestic workers. Many of them

6 See <http://www.ilo.org/global/about-the-ilo/decentwork-agenda/social-protection/lang-en/index.htm> 30 October 20I2). 
(though it is hard to give exact figures as the women interviewed mostly did not want to share this information) came to Spain on the agricultural work scheme while their husbands were already in Spain. The husbands did not fulfil the conditions to allow their wives to join them under family reunification rules (due to insufficient funds to pay for a large apartment or social security dues) and some of them instead preferred to send them money to bribe the Senegalese officials in order to be selected for the temporary work scheme (see discussion below). Other women interviewed were in a legally irregular situation because they had stayed in Spain and worked without a permit and therefore had not paid their social security contributions. This situation is an obstruction to attempts to renew their residence permit in Spain.

In total, 525 Senegalese women migrants in Spain were surveyed during the period March 2010 to October 20II. The questionnaire included closed and scaled as well as open questions and focused on their migration histories, life and work conditions, and economic and social situation. ${ }^{8}$ In addition, semi-structured interviews were held at both workplaces and homes with a sub-sample of thirty-three women with relevant experiences in order to deepen some insights gained from the survey data, notably the challenges they face in accessing and/or ensuring respect for their social protection rights. The meetings with the respondents were made possible largely through mi-

7 "La protection sociale des migrantes Sénégalaises évoluant dans les activités agricoles et les services aux particuliers en Espagne" (translated as "Social and Health Protection of Women Migrants from Senegal in Agricultural Activity and the Personal Care Industry in Spain"), research conducted by Le Groupe d'Etudes et de Recherches sur les Migrations (GERM), Université Gaston Berger de Saint-Louis (Senegal), funded by the International Development Research Centre (IDRC), project number I05463-OOI. For the final research report, see Tandian, Coulibaly, Sow, Tall, Wade, Dioh, Dime, Ba, Badji, Gueye, Mbaye, Tandia, Diallo, Diagne, Mbengue, Vasquez, Seron, Kebe, Sane, Thiakh, Thioye, Gueye, Niang, and Ciss. (20II). See also <http://www.germ.sn/ index.php? option $=$ com_content $\&$ view $=$ article $\& i d=39 \&$ Itemid=IO6> (30 October 20I2). The data collection team consisted of Senegalese who had lived in Spain for at least a decade. Some team members were or are enrolled in the Ph.D. programme at the Complutense University of Madrid and at Barcelona University.

8 The total number of questions was 26I, of which 18 addressed sociological identification, 36 previous activities and migration patterns, 36 marital and family status, 45 living conditions, II5 working conditions, and I2 the economic and social situation of migrant women. grant associations and their networks. At the start of the research, a database was constructed with fiftyone Senegalese migrant associations in Spain.

The sampling of the respondents was carried out by the snowball technique in various Spanish cities (Barcelona, Lerida, Valencia, Madrid, Murcia, Huelva, Granada, Malaga, Seville, Almeria, and the Canary Islands). Snowball sampling was necessary because of the lack of detailed official data on Senegalese women migrants in Spain that would have allowed for choosing a representative sample based on socio-professional and socio-demographic variables. Selection criteria of the snowball sample included: gender (female), profession (working in the agricultural and personal care sectors), length of stay (having lived in Spain for at least six months), and length of working in the same sector (at least three months). For the survey, an additional selection criterion for choosing the cities was the density of the Senegalese male and female migrant population (on this, official data exists $\left.^{9}\right)$. As for their educational status, thirty-three per cent of the women in the sample have completed primary education, thirty-six per cent have completed secondary education, and only two per cent have no education at all.

In the pre-fieldwork phase, interviews were held in Senegal with officials at the Labour Directorate, the National Youth Employment Agency, and the Ministry of the Interior on the immigration policies and mechanisms relating to migrants to Spain and the migrant worker selection process. In Spain, officials at the Senegalese consulate and migrant association leaders and members were interviewed in order to contextualize the implementation mechanisms of the migration scheme and investigate the extent to which migrants' rights are respected.

The main research challenge lay in having to overcome the suspicion of respondents, some of whom only agreed to be surveyed or interviewed in the presence of their husbands (due mainly to sociocultural norms). Some women wrongly assumed that the researchers were a mixed team of Senegalese and Spanish journalists, or that the Senegalese researchers were

9 In Spain, even irregular migrants can sign up with the padron municipal (the municipal registry), thus gaining access to social services (e.g. health care). This means that the country has relatively good estimates of the numbers of its irregular immigrant population. See the publications coming out of the MAFE project, which relied on data from the padron municipal for sampling purposes (<http://www.mafeproject.com/> (30 October 20I2). 
mere facilitators helping Spanish researchers to collect information from Senegalese migrants. This distrust can be explained by the fact that the survey was conducted only shortly after the broadcast, on a large scale, of Spanish TV documentaries chronicling the escape of Senegalese women sent to Huelva. Moreover, prior to the data collection period, a Spanish newspaper had published articles that drew links between prostitution and the presence of sub-Saharan migrants in Spain. Thus, building relationships of trust was a major challenge and a time-consuming activity. Using migrant associations and other gatekeepers and key informants as intermediaries was useful in this regard.

\subsection{Senegalese migration to the EU and Spain: A Brief History and Institutional Framework}

This section first gives a brief overview of the history of Senegalese migration to Spain, and then focuses on the institutional and legal framework governing Senegal-EU and Senegal-Spain migration and the Spanish labour market. Individual women migrants' decisions at the micro-level need to be placed in a broader perspective of the functioning of labour markets and states to understand the possibilities and constraints they encounter (Van Nieuwenhuyze 2009: I3).

While a detailed history of Senegalese migration to Europe is beyond the scope of this paper (see Van Nieuwenhuyze 2009: 67ff.; Kaplan Marcusán 2005), it is clear that the Structural Adjustment Programme conducted in Senegal during 1982-I992 resulted in a combination of economic growth with greater poverty, and a fifty per cent currency devaluation in 1994 increased the importance of remittances from abroad. More families invested in an international migrant, with the orientation shifting from France to other countries such as Italy and Spain, reaching three million out of eleven million Senegalese living abroad (Van Nieuwenhuyze 2009: 72-75).

Citing a 2002 survey of the labour market in Dakar of the Organisation for Economic Co-operation and Development (OECD 2005), Van Nieuwenhuyze (2009: 75) points out that underemployment (adding the unemployed to those working less than the official working hours and those working for less than the minimum wage) "hits nearly 72.5 per cent of the active population in Dakar". Apart from poverty and being pushed by family members, ambition and curiosity are also important factors in the migration decision. Indeed, Senegal is a country with a deeply rooted and long tradition of migration. The journey is assimilated in Senegalese society as something positive because it is supposed to build character and allow the one leaving to acquire material and/or intangible goods, even though it may entail difficult experiences. Migration thus represents for many young Senegalese the ability to access a first job that they would have little chance of finding in their own country (Bocquier 1992), while their elders see it as the only solution to improve a daily life marked by the "goorgoorlu" or "daily getting by" (Fall I998). Particularly now that education no longer represents social mobility in Senegal, (temporary) migration is seen by all segments of society as the only way to survive economically and, more importantly, to be someone (Van Nieuwenhuyze 2009: 76; see also Riccio 200I). As we will see below, in the face of Europe's closed doors, immigrants develop strategies to circumvent migration laws, as "legal and bureaucratic obstacles to migration and settlement are seen not as absolute barriers, but as factors to be taken into account in personal strategies, migration networks and community infrastructures" (Van Nieuwenhuyze 2009: 77, citing Castles 2002).

Though "the Senegalese migration to France has long been boosted by the special relations with the former colonial power, ease of movement and linguistic ties, French being the official language of Senegal" (Tall 2008: 42), the key turning points were the closure of French borders to labour migration in 1974 and the introduction in 1985 of visas for some African nationals, including Senegal, issued under certain conditions under the Schengen Agreement (Tall 2008). These processes affected the profiles of Senegalese migrants as well as their conditions of departure, arrival, settlement, and mobility. They also intensified the feminization of Senegalese migration to France as after 1974 family reunification became a major means of legal entry into France. Moreover, Senegalese migrants increasingly migrated to Spain and Italy, reflecting a change "in the spatial configuration of their mobility in Europe" (Coulibaly-Tandian 2008: 72).

Several factors explain this redeployment to Spain. In its early days, mainly "illegal" migrants were attracted by the relative permeability of the Spanish borders. Later, although Spain had begun to implement a migration policy in 1985 (see below), there were gaps. The Senegalese, like other migrants who arrived in the country, took advantage of legal loopholes to enter and settle there, especially because of the possibility of bringing their families to the country (Robin 
1996). The choice of Spain can also be explained by its economic dynamism in the labour-intensive small and medium enterprises and industries sector (especially in its vibrant underground economy) that required a massive and low-skilled workforce (Tall 2008).

To this diversification in terms of new destinations was added a diversification of origins, categories, and profiles of migrants. The profile of the migrant cannot be reduced to the classical picture of a rural and illiterate male. "The old figure of Senegalese migrants made up of rural and illiterate gives way - but without disappearing - to new players who have strong professional or human capital and are, generally, from the urban areas" (Tandian 2008: 366).

Here, women are gaining increasing importance among the migrating Senegalese. Most of them migrate within family reunification schemes, or to work or study. In doing so, some migrate legally and others illegally. Coming in the name of family reunification does not prevent these women from having an economic migratory project, however, even prior to their departure from Senegal. Today, Senegalese women migrants in Europe, generally speaking, have very varied characteristics and profiles both in regard to their geographical origins and socio-economic and education levels and motivations for migration. And whatever their migration conditions are, they almost all carry an individual and family economic migratory project (Coulibaly-Tandian 2008).

Indeed, the migration of Senegalese women to Spain has reached unprecedented numbers. According to the National Institute of Statistics, in 2009 there were 56,048 Senegalese in Spain, of whom 46,858 were men and 9,I90 women (Instituto $\mathrm{Na}$ cional de Estadística 2009). ${ }^{10}$ These data are however to be put in perspective since many Senegalese living in Spain had not been identified at the time of the census. Most Senegalese women migrants are settled in Catalonia and Andalucía. This trend is reinforced as Spain is implementing quota policies resulting in employment contracts that favour women, as we will see below.

While the main focus of this chapter is on Senegalese women migrants who came to Spain as part of a temporary agricultural work scheme which they subsequently abandoned, mainly to work in the personal

10 Data for 2009 were obtained from the online database of "Municipal Register Population Figures" available at: $<$ http://www.ine.es/jaxi/menu.do?type $=$ pcaxis\&path $=\%$ 2Ft20\%2Fe245\&file=inebase\&L $>$ (I9 November 20I2). care sector, there is of course also the second, and arguably much larger, category of Senegalese women migrants who came to Spain independently of this or any other scheme (see García-Cano 2002). The latter generally work in the trade in exotic products, the catering and hotel sector, hairdressing, and personal care/domestic work. It should also be noted that it is not uncommon to find women who combine several activities. Although these women, often without professional training, have more chance of finding a job in Spain than in Senegal, they are concentrated in precarious, poorly paid, and low-status sectors. There are however also health workers and teachers for whom it is easier to obtain a visa to enter Spain as they fulfil the conditions (bank statement, professional identity card, etc.) and are considered by the Spanish consular authorities more likely to return to Senegal. These women often apply for a short-stay visa but then overstay their visas and acquire irregular immigration status.

We now turn to a short discussion of the changes in the Spanish economy and the labour market as well as the migration framework to provide the context for the research findings.

Since the economic downturn of the I970s, many European countries have experienced post-industrial economic restructuring, in which Fordist structures of mass production and rigid labour markets have been replaced by highly fluid and flexible production arrangements and labour markets, with an emphasis on new intermediate and support services, locational advantage, and changes in private consumption patterns. The 'casualization' of employment is reflected in downgraded and informal sectors staffed by migrant workers. Their lives and strategies are heavily influenced by the degree of protection in the labour market and the rules for redistributing welfare benefits by the state (Van Nieuwenhuyze 2009: 3I, 34).

Spain has only recently (in the last two decades) changed from being a labour exporter to becoming a country of net immigration. The low productivity sectors (intensive agriculture, tourism, construction, and small industries) have had to become dependent on immigrant workers from poor countries in order to stay competitive. These have also increasingly become part of the informal or underground economy which in 2000 represented twenty-two per cent of the total economy. Furthermore, temporary and part-time jobs represent more than thirty per cent of all jobs (Van Nieuwenhuyze 2009: 46-48; see also European Migration Network (EMN) 20IO).

Spain's recent status as a net immigration country ${ }^{11}$ and pressure from the EU explain the relatively 
rapid development of new laws imposing visas and work and residence permits, and establishing social and political rights. Most authors seem to agree that these represent an "ineffective attempt to organize legal entry, curtail illegal entry and regularize those already inside" (Van Nieuwenhuyze 2009: 37-38, citing Freeman 1995). This outcome reflects the tension between two opposite policy logics: compliance with strict border control polices as demanded by the EU (of which Spain has been a member since 1986) on the one hand, and the fulfilment of the need for unskilled workers in agriculture, industry, and services on the other (Van Nieuwenhuyze 2009: 49).

This tension explains the existence of legal restrictions that hardly allow other working possibilities for immigrants than the work in specific niches marked by precariousness and uncertainty and defined as "new employment mines" (Agrela Romero/Gil Araujo 2005: 5, cited in Dobner/Tappert 20IO: 7). As a consequence, three-quarters of the immigrants in Spain work in five labour market sectors: domestic work, agriculture, hotels and catering, construction, and the retail trade. These sectors represent less than forty per cent of the labour market (Dobner/Tappert 20IO: 7). ${ }^{12}$

The first Spanish law to regulate immigration was the 'Foreigners Act' in I985, widely regarded as controversial, restrictive, and discriminatory. It was replaced by a new 'Foreigners Act' in 2000 that hardened many conditions, including increasing the period of residence required for individual regularization from two to five years (Van Nieuwenhuyze 2009: 49). ${ }^{13}$ Regularization campaigns have been used on six occasions (I986, I99I, I996, 2000, 200I, and 2005) to try to address issues of exploitation and marginalization. As Van Nieuwenhuyze (2009: 50) states, "by legalizing all immigrants they give migrants living in Spain without a working permit or residence permit access to a legal and administrative status and facili-

11 Spain saw a more than fivefold increase in the number of immigrants between 2000 and 20I0, though annual growth has declined significantly since 2008 (EMN 20IO: 19-20). Despite the rapid increase, (legal) immigrants represent only two per cent of the country's population (Solé/Parella 2003: I2I-I22). In 2006, four per cent of the total immigrant population in Spain was from sub-Saharan Africa (see Lessault/Beauchemin 2009).

12 See also Corkill (200I) for a discussion of the Spanish labour market for migrants.

13 For more details on the 1985 Immigration Law and subsequent legal changes, see Solé/Parella (2003: I27ff.) and Mendoza (200I: I69ff.). tate their access to markets (labour, housing, banking, etc.) and public services (social security, education, health, personal social services, etc.)". The campaigns could however be criticized as providing strong incentives for further undocumented migration. Spain also adopted a quota system in 1993, but instead of attracting new workers, it functions more as a concealed regularization mechanism for migrants with irregular status already in Spain. A complicating factor is Spain's advanced degree of decentralization, which means that migration issues require the collaboration of both national and local levels (Van Nieuwenhuyze 2009: $46,50)$.

As a receiver of circular migration, Spain has considerable experience with non-European groups, particularly Moroccan workers. The first major Moroccan migration to Spain in search of work occurred in the I980s and was aimed at the agricultural areas of Catalonia's Maresme region, at a time when Moroccan citizens could travel to Spain without a visa. Both then and in the I990s (after the visa requirement was introduced in I99I but when irregular migration between Morocco and Spain was still in practice an easy option), many of the Moroccan migrants were actually practising circular migration, combining their work and period of residence in Spain for some months with farming activity and maintaining their family and home in Morocco. When irregular immigration became more difficult due to legal changes and increased monitoring of the Straits of Gibraltar (mainly since 2002), this kind of back-and-forth migration became impossible, especially for immigrants whose situation was still irregular and who did not wish to risk having to return to Morocco. From then on, circular migration was regulated through international agreements and was legally channelled via quotas. Romanians, Bulgarians, Moroccans, Ecuadorians, and Colombians made up the bulk of this contingent until the first two nationalities became able to migrate freely from January 2009. The total number of immigrants using this channel, mainly for seasonal agricultural labour migration, is very small compared to the total inflow, although, following the restrictions imposed on the arrival of new labour immigration as a result of the economic crisis, it has become one of the few means of legal immigration (González Enríquez 20II).

In terms of social policies, the Spanish welfare system pays lower benefits compared to other OECD countries, relying on family networks. As for migrants, "since the 2000 law, legal immigrants have the same civil and social rights as Spanish nationals, and 
undocumented immigrants have the right to basic social rights such as free access to public health care services, free compulsory education (three to sixteen years), and the very scarce public housing. This is based on the criterion of residence, explaining why even undocumented immigrants inscribe in the census" (Van Nieuwenhuyze 2009: 5I). However, specific policies are mostly reactive, and "many migrants rely on third-sector organisations and social services that help undocumented immigrants, often with support from state administrations", though these are very much locality-specific (Van Nieuwenhuyze 2009: 5I52, citing Domingo/Kaplan/Gómez Gil 2000).

In short, current migration policies, a segmented labour market, and a growing informal economy in Spain have led to an ethnicized and gendered labour market. Solé and Parella (2003: 124) define the Spanish labour market as 'ethno-stratified', in which immigrants are employed in the lowest positions, due to, among other reasons, the discriminatory practices of employers and the state, rather than a lack of qualifications.

Indeed, it has been argued that in Spain, the immigrants from the Third World, from different races and cultures, are facing racist oppression in addition to that related to their social class or gender. "This threepronged oppression puts the migrants in a position of extreme subordination regarding the power relations within the host society" (Solé I994: I5). In other words, Senegalese women of different culture and skin colour experience many difficulties in the Spanish labour market. This is especially the case in the domestic work sector, where, as Falquet, Hirata, Kergoat, Labari, Le Feuvre and Sow (20IO: IOI) observe, women are by definition 'invisible' to outsiders, "supporting children and the elderly and other hardly 'delocalizable' tasks, performed in families whose income allows the outsourcing of those activities in a specific social relationship, the one of domesticity. These women are most often without legal status [...] and have frequently left their own children and extended family in the country. Opinions differ on the consequences of their migration, because they are based on a sociocentric [and Western ethnocentric] conception of what is women's autonomy or the 'subject' and her 'desire', although of course, the individuality of these women cannot be reduced to the work they perform and that they have often not chosen to do."

These observations are linked to those made by feminist economists who have shown that deregulation and free market policies have created working conditions rather unfavourable for women. These pol- icies have increased the supply of certain jobs on the one hand but increased women's workload of paid and unpaid work on the other. This brings out the problem of reproduction and/or extensions of domestic work in the North, a question often concealed in conventional analysis (Sassen 2000). Irianto and Truong (this volume, chapter 2), analyzing the transformation of relations that organize domestic work, point out that such work "must be seen as contextual and nested in a mixture of care-related institutions within a broader policy framework concerning gender equality, the family, and women's economic participation in a nation state". We will return to some of these observations below with regard to the Spanish case.

\subsection{The Temporary Agricultural Work Scheme: Process and Outcomes}

This section discusses the temporary agricultural work scheme launched in 2007 that included more than 700 Senegalese women coming to Spain for three to six months, starting in January 2008 for the strawberry harvest in Huelva; many subsequently abandoned their workplaces to find other jobs, mainly in the personal care sector in Spain. The main dimensions of this case study are illustrative of other, similar schemes around the world ${ }^{14}$ and include weaknesses in the selection processes and hardships in the work itself linked to the nature of the work contracts, the relationship with the employer, living conditions, and finally, the nature of the work itself.

Before considering the case in more detail, it is useful to briefly review the main legal provisions for temporary migration to Spain. Indeed, the bulk of the temporary and circular migration entering Spain is coordinated through recruitment schemes for agriculture (EMN 20IO: I4). The general legal framework established by Organic Law 4/2000 introduced the possibility of residence and work permits for seasonal work under a special scheme while maintaining the association with the 'contingent' (Contingente de Trabajadores Extranjeros), the general programme for foreign seasonal workers who do not enjoy free circulation within the EU labour market. Newland, Agunias, Dovelyn and Terrazas (2008: 7) summarize the key features of the programme as follows.

14 For example, see Siregar (2010), Morgan and Nolan (20II) and Irianto and Truong (chap. 2 above) for similar issues with bilateral agreements on Indonesian migrants. 
It is annually adjusted by province and sector according to needs and establishes an easy procedure for hiring seasonal workers, for no more than nine months per year. The Contingente encourages circular migration with a combination of demands and incentives. First, it requires participating migrants to sign a binding commitment to return to their country of origin at the end of the work season. Migrants must register with a Spanish consulate in their origin country; the consulate then monitors compliance. A worker who returns home can participate in the program again without going through the selection process. After four years of following the rules, the migrant gains easier access to permanent work authorization.

The recruitment of seasonal workers in their countries of origin has thus come to be one of the main ways of managing migration flows and an important source of labour for seasonal work. Through this system, employers can offer temporary or seasonal jobs and contract work for a specific project. According to the provisions of article 39 of Organic Law 4/2000, vacancies can be generic or nominative (for hiring named individuals; EMN 20IO: 20-2I, 27; see also Kohnert 2007: I7).

Since 2000 , bilateral agreements have constituted an important mechanism for recruiting workers (both stable and seasonal) in their country of origin. Nonetheless, since 2004, the agreements have included a new dimension that now entails, in addition to worker recruitment procedures, flow control, the prevention of illegal immigration, readmission procedures, and development cooperation. These "second generation" framework agreements on migration aim to adapt the profile of workers to the structure of demand in the Spanish labour market while also fostering the development of countries of origin. At least in theory, they include actions to distribute information on channels of legal migration and the risks of their illegal alternatives, to promote training in the country of origin, and to set up offices for technical cooperation. To date, Spain has signed bilateral agreements with Colombia (200I), Ecuador (200I), Morocco (200I), the Dominican Republic (2002), Romania (2002), Bulgaria (2003), and Mauritania (2007). It has also signed cooperation agreements on immigration with The Gambia (2006), Guinea (2006), Guinea Bissau (2008), Cape Verde (2007), Mali (2007), Senegal (2007), and Niger (2008), all of which are second-generation agreements (EMN 20IO: 34).

In the case of Senegal, and with the assistance of the International Labour Organisation, a board of employment has been set up in Dakar to select candidates, manage the administrative processing of per- mits, and train workers for employment in Spain. In 2007, the agreements signed with Senegal led to the hiring of 700 female workers on farms in Andalucía and a further 2,000 (mainly male) on Spanish ships. ${ }^{15}$ Workers from Mauritania (2008) and Mali (2008 and 20I0) have also been recruited during agricultural seasons in recent years (EMN 20I0: 35; Burnett 2007).

The social protection conditions for workers who have been recruited collectively in their country of origin for fixed-term work and with a residence permit and who start work in Spain seem to be adequate, at least on paper. For example, they must register with the social security system at the start of their employment and may register as jobseekers with the public employment services if they lose their job before the end of the validity period of the permit or of the employment. They are however exempt from unemployment contributions but mandatory contributions are payable to cover the costs of occupational and nonoccupational accidents and illnesses. As mentioned earlier, they must agree to return to their country of origin at the end of the employment relationship. To verify that this return has indeed taken place, the worker must visit the diplomatic mission or consular office within one month of the end of his or her permit for work in Spain (EMN 20IO: 28-29, 3I).

On the part of the employer, Spanish legislation for seasonal workers requires them to guarantee decent accommodation with appropriate hygiene conditions and to organize the journey to Spain and back to the country of origin, bearing at least the cost of the first of these journeys and the expenses of transfer to and from the point of entry into Spain and the worker accommodation. Monitoring of compliance with accommodation conditions is carried out through the Work Departments and Provincial Labour Inspectorate. The legislation also requires diligence on the part of employers in ensuring that workers return to their countries of origin at the end of the employment relationship (EMN 20IO: 3I).

However, as will be shown below, experiences under the labour scheme as related by the migrant workers themselves contrast quite significantly with these provisions.

The political context in which the bilateral agreement that launched the scheme was signed on 9 November 2007 is important here. Senegal announced the scheme (the first of its kind) after it agreed to take back hundreds of illegal Senegalese migrants from

15 The findings presented here only discuss the experiences of the female workers in the agricultural sector. 
Spain in September 2007. A year earlier, in 2006, about 30,000 illegal immigrants had arrived in Spain, mainly on the Canary Islands, of whom at least half were Senegalese. Thus the scheme was seen by government leaders as a major way of combating illegal immigration. ${ }^{16}$ Perhaps Senegal also tried to use the threat of more illegal migration as a bargaining chip in achieving debt relief, more development aid, and eventually also more opportunities for legal employment-related migration. ${ }^{17}$ The fact that President Wade was preparing his re-election campaign at that time may also have played a role.

After the agreement was signed, Spanish job offers for 744 Senegalese women were received through the Spanish Embassy in Dakar, based on a quota determined by the Spanish farmers' union of employers. Under the terms of the contracts, the cost of travel from Senegal to Spain, around 600 euros or more, was to be covered by the employer. However, this amount was to be deducted from the salary paid to the worker. The agreement also stipulated that Senegal would deal with the selection. The key selection criteria were being female, competent in doing farming work, and originating from a rural area in Senegal. The Spanish government committed itself to taking care of the formalities for visa and travel arrangements in Spain through its appropriate structures.

The criterion for selecting female workers only was explained by the Senegalese Ambassador in Spain in an interview as follows: "For the choice of women, you know, the strawberry is very sensitive; it takes a lot of attention for the picking. Here you are! You know the women have hands that are very different from men's. They can pick strawberries without squashing them. I think that's why Spain wanted women to be recruited." However, a more convincing reason for selecting only female workers is probably that Spain anticipated problems with workers not re-

16 This reading was confirmed in an interview with the Senegalese Ambassador in Spain.

17 Earlier agreements between Senegal and Spain include the following but do not explicitly address issues of social protection: Framework Agreement on Cooperation for Development, signed on Io October 2006; Joint Statement on the management of migration flows of 5 December 2006; Agreement on the prevention, protection, repatriation, and reintegration of unaccompanied Senegalese migrant minors, signed in Dakar on 5 December 2006; Declaration of Intent signed in Dakar on I5 February 2007 between the Spanish Minister of Labour and Social Affairs and the Senegalese Minister of Youth and Youth Employment. turning to Senegal at the end of their contracts. Newland/Agunias/Dovelyn/Terrazas (2008: 8; see also González Enríquez 20II) report experience with an earlier seasonal worker programme which Spain had implemented progressively since 1999 and the European Union supported since 2005, and which opened legal channels for Moroccan women to work in the citrus and strawberry industries in and around Cartaya, Spain.
Although return of the workers was one of the pro- gram's objectives, only 5 percent of the 1,200 participat- ing workers in 2005 went home; in 2007 , therefore, only married women with children were selected for the pro- gram - and they were not permitted to bring the chil- dren with them. If they returned on schedule, they were guaranteed a job for the next season. After the 2007 sea- son, 85 percent of the 4,563 workers returned voluntar- ily.

In any case, the selection procedure was hampered by the lack of coordination and clear mandates of the various agencies involved, though according to some members of the National Commission for Management and Monitoring of Job Offers and members of various NGOs, the National Agency for Youth Employment (ANEJ) was the only institution that actually managed the selection of agricultural workers. According to the Executive Director of ANEJ,

the management of the departure and accompaniment of the selected workers was chaotic because of several changes in the staff in charge of the trip, linked to the governmental instability experienced by Senegal [...]. This has greatly affected the administrative structures of the various ministries involved in the management of Senegalese migration. ${ }^{18}$

Another level of dysfunction was found in the targeting or profiling of the candidates. During an interview, an official at the Ministry of Youth argued that "candidates had to submit a file including a medical certificate proving their good health, a certificate of training in agriculture and horticulture and the degree obtained". This contrasts with his later admission that "some girls expressed concerns about their abilities to do the job properly", and leads us to doubt the official view according to which Spanish employers were adequately represented in the recruitment commissions and had heard the candidates. This doubt seems justified in the light of complaints by Spanish employ-

18 Statement given during the launch ceremony of the research project on "Social protection and Senegalese migrants working in agricultural activities and personal care services in Spain", University Gaston Berger of Saint-Louis, Senegal, 26 June 2008. 
ers as well as women migrant workers about their difficulties of adapting to life and work in Spain and their declarations of illness. According to the Spanish recruiters, who went as far as insulting the Senegalese workers as 'lazy' or 'Naomi Campbell' and so on, some women became pregnant, in addition to many cases of unavailability due to illness. Moreover, even though a youth inspector said he did not see any cases of corruption in the recruitment procedure, he did mention having been the target of an attempted bribe by the parent of two girls who offered him two million CFA francs (3,000 Euros) in return for their selection.

Most importantly, the main stakeholders, namely the female agricultural workers selected, were not involved in drawing up the contracts, which led to their not being aware of their contents. During an interview in Seville, a Senegalese trade unionist observed:

I have heard that the girls did not know the terms of contracts, nor the conditions under which they were to work in Huelva. But again, I say this is the error of the Senegalese state, because it seems foolish to engage nationals without the support of a lawyer or a labour inspector. They signed without knowing what is stipulated in the contract, the salary procedures, the accommodation, etc.

The women interviewed in this study confirm this lack of detailed information concerning their tasks, remuneration, accommodation, working hours, etc. A woman selected at Diourbel and whom we met in Barcelona shares her experience:

As for the contract signed before coming, we did not even read it; we did not even know what it was about and the people who accompanied us told us nothing clearly on the contract. They only showed video images explaining the work in a strawberry field, not more. They also affirmed that we would be housed in apartments with all amenities required and that we would live in a good family atmosphere. Instead, we were thrown and enclosed in a kind of bush with no electricity or any type of basic convenience, with eight people sharing small rooms and not knowing the language. At Diourbel, after the interview they made to test our willingness and ability to work in fields, they had us sign some papers, but we do not even know what we have signed. Everything was in Spanish! Nothing was written in French! In Huelva, regarding the payslip, we have never had or seen one. Everything was confused with the story of labour contracts. I have no doubt that some women have the skills to work in fields. They are used to it. They did so for several years in Senegal, but next to them there are women who have paid to be selected. The women had promised to keep quiet but facing reality and the many difficulties, there was noise. Lots of noise. I preferred to go do something else and I do not regret it (Aissata ${ }^{19}$, who came to Spain for agricultural work, Barcelona).

These political and institutional failures, including lack of information about their work contract and salary, attempted or real bribery, and the dire living and working conditions arguably are part of the reason why migrant workers returned prematurely from Spain or 'escaped' to work in other sectors and lead us to question the viability and the transparency of the selection process. Admittedly, the negotiating capacity of these women was very limited during the recruitment process despite their regular status. They contented themselves with having been chosen among many in a Senegalese context where migration is highly valued and travel opportunities to Europe very limited.

As Van Nieuwenhuyze (2009: I06) points out, given the fierce global competition in the agriculture sector, it has some of the worst labour conditions in the informal sector, for both migrant and Spanish workers: workers need to be available (often staying at the farm), flexible in terms of overtime and able to accept that there may not be any work at all at times, and hard-working (accepting physically hard conditions). Salaries are low (about three euros an hour) and employment is never long-term or secure, as it depends on how weather conditions affect crops. Almost all work is therefore temporary. The trend towards casual work has increased with new laws imposing heavy fines on employers hiring clandestine workers, although labour inspections are relatively rare (Van Nieuwenhuyze 2009: I06-IO7, II6; Corkill 200I: 835). It is therefore no surprise that while agriculture is definitely a very common first employment sector for African (undocumented) migrants, most of them try to leave it as soon as possible for a more secure job in another sector (Hoggart/Mendoza I999, cited in Van Nieuwenhuyze 2009: I69).

Indeed, as mentioned earlier, the contracts stipulated that the Senegalese migrant workers were to return to their home country at the end of their activities. However, some preferred to stay in Spain by their own will or under the influence of their relatives. At Lavapies, a neighbourhood of Madrid, one of the Senegalese agricultural workers told us:

I had an employment contract for three months, but I worked for two months and fifteen days. [...] Fifteen days before the end of the contract I went to join my brothers. If I had not done it, my boss would have taken

19 All names of Senegalese women migrant workers have been anonymized. 
me back to Senegal. For me it was not an escape but a reasonable choice I made on the advice of my brothers, who have been living in Spain for several years (Aminata, who came to Spain for agricultural work, Madrid).

The first results of this temporary migration scheme suggest that migrants and their Spanish employers are disappointed by its method of operation, agreed at the highest level between the governments of Senegal and Spain. The strategy that was supposed to provide employment opportunities for migrants only increased the number of migrant Senegalese living clandestinely in Spain. The Spanish government authorities remain silent about future temporary migration schemes. The Spanish employers' refusal to renew contracts and to continue the programme is undoubtedly one more obstacle for the Senegalese migrants who have remained in Spain. According to EMN (20IO: 25-26), criticisms of this and similar programmes have also been aired over the last ten years by Spanish representatives of trade unions, NGOs, migrant associations, and the scientific community. On the selection of countries with which bilateral agreements have been signed (especially from 2000 to 2004), they argue that the criteria were motivated by reasons of diplomacy and strategic positioning and do not always coincide with the approach of the longterm migration policy or the true features of the flows of migrants they should be addressing. Secondly, there has been criticism that the procedures for the recruitment of foreign workers by employers do not include measures to guarantee that they are based on criteria of qualifications and experience, as opposed to cultural or racial preferences. However, it seems that for subsequent temporary work schemes, the selection procedures have been clarified, streamlined, and better coordinated (see EMN 20IO: 28 for details).

\subsection{Becoming a Migrant with Irregular Immigration Status: Senegalese Women in the Domestic Work Sector in Spain}

Some Senegalese women agricultural workers managed to 'escape' from their jobs in the agricultural sector through the complicity of their families who had been established in Spain for several years. ${ }^{20}$ From the survey, we learnt that some women abandoned the fields to join their husbands or family and friends in other cities in Spain (Barcelona, Seville, Madrid, Almeria, etc.) and Italy by car or train. Indeed, arriving in
Spain for the picking of strawberries seems to have been for many of them a mere pretext for easy access to Europe.

By abandoning their jobs and moving to urban centres, the women in fact became migrants with 'irregular' status, as the temporary residence permit with which they were able to travel to Spain obliged them to settle in the territories where they were recruited. In addition, the permits did not allow them to carry out any activity other than agricultural work. However, for some women, abandoning the fields clearly represented a better alternative to the harsh working conditions, even though they faced an uncertain future. Many ended up in the personal care/domestic work sector. Khady explains that after leaving the greenhouses in Huelva, she joined some friends settled in Barcelona. She lived for some time with them before leaving for Tarrasa:

After leaving the strawberry fields, I was trying to sur-
vive as I could. I joined some hairdresser friends and
that is what explains my initial presence in Barcelona. I
met with associations and I joined them thinking that
my living conditions would change, but as you can see
here, this is not luxury. It is a life of getting by day by
day! I have a membership card of the Association of
Senegalese in Catalonia, but I do not take part in their
activities. With my irregular situation, I preferred to
leave again and I moved to Tarrasa. I do odd jobs in
homes. I clean, I sweep, and I sometimes cook! It's bet-
ter than nothing, isn't it? (Khady, Barcelona, 37 years
old). Just like Khady who recently settled in Tarrasa to escape the harsh conditions of agricultural work, many Senegalese women left for other Spanish cities where they hoped to find new and less harsh job offers than those in Huelva. Very often they only found domestic work, as their new status does not facilitate their professional integration especially with the financial crisis affecting Spain (see below). Domestic work is the most accessible employment because many employers pay no attention to the legal status of their regular employees. Indeed, employees with irregular status are often preferred as their legal status prevents them

20 There are no exact figures available as to the extent of this phenomenon. According to comments gathered from several women who came to pick strawberries, more than half of the workforce defected to other Spanish cities or travelled to Italy. Tall and Tandian (20IO: II) mention the case of 70 women out of 540 who arrived in March 2008 and who did not report back when their contracts were discontinued or ended, i.e. about I3 per cent. 
from taking legal action in case of abuse. In the light of this precarious legal status, these migrants have very limited flexibility in their choice of employment, which explains their low bargaining power at the time of recruitment.

As indicated earlier, apart from the migrant workers who initially came to Spain on the agricultural work scheme, other Senegalese women working in domestic work came to Spain much earlier, as individuals or as part of family reunification. Those who came as part of family reunification usually have regular status and work with contracts through placement agencies while the others usually have irregular status and are self-employed, seeking their own clients and often working without a written contract, relying on an oral agreement. Their salary varies greatly because they can charge by the hour or by the day or specify fixed rates, depending on the assignment. Their working hours may be longer than those of contract workers but this seems to be perceived as a privilege because these workers can earn more, even though they are excluded from social protection. ${ }^{21}$

During a discussion, some migrants emphasized the ambiguity they live in: on the one hand, they are forced to keep their jobs even if they mean drudgery, harsh requirements by employers, and their own acceptance of the undesirable, while on the other hand, once they are determined, some migrants successfully manage to abandon domestic work if the work conditions become too difficult. This experience is illustrated by the following interview quotes:

At the home where I worked, there were eight rooms, five toilets, a tennis court, a bar, a large swimming pool. The house was so big that I cannot tell you the actual dimensions (...) and I was alone cleaning it, I was doing all the work. Can you imagine? (Fatima, 35, Valencia).

You know, if you are recruited for a job that you have never done in Senegal, it is normal that you suffer. And if you come across a demanding boss who does not value your work, as is often the case, things may be very complicated. I know Senegalese whose employers were very difficult. They also left their jobs after a few months. According to them, their work became pure exploitation. You know, sometimes women are forced to stay because they have no alternative but to endure what the employers demand. When you are in need, you

21 In Spain, three different subforms of domestic work are distinguished: internas (live-ins), externas (live-outs) and 'por horas' (hourly workers). Every sector presents different schemes for payment, duties, and hours of work (Dobner/Tappert 20I0: 2, footnote 3). can only resign yourself and bear all conditions (Yacine, 42, Valencia).

Facing these difficulties in domestic work, some women feel that street vending (of belts, glasses, etc.) is less restrictive although they recognize that with street trading, there are risks such as being chased by the police. Other women migrants feel that the benefits of street trading, as opposed to domestic work, are first, not to be regarded as a mere "slave" and secondly, to make money without having to endure an employer who demands the resumption of a task already done.

I think I was like a slave! I had no freedom. Not at all! I was only earning a small salary despite all the work I was doing. The salary did not match what I really deserved! I was not allowed out! My boss asked me to wake up at 7 a.m. and if I was not up she would come and wake me up before returning to bed. I was preparing breakfast before she woke up around 9 a.m., that is to say, two hours after me! I had to work hard for everything to be clean before they woke up. Once she was up I served them breakfast. And after all this, I cleaned the table and then walked the dog. It was slavery! It was really slave labour! (Fatim, 40, Madrid).

With domestic work, I was like a slave; this is how I could describe myself! You know why? It's because it is not possible to measure the heaviness of the work I performed! And then I had no freedom! Someone who works without freedom, what is she? What can she be called? Freedom is priceless and I had none at all! (Awa, 42, Madrid).

In addition to long working hours, some women suffer from isolation, a situation they have difficulty in accepting.

On some points, I can say I was treated well by my boss and her children. They gave me enough to eat and drink. But it is the isolation that bothered me. It hurt a lot! I was sidelined as if I had a disease and paradoxically it is me who was cooking for them! It was very painful to feel isolated! Yet it was me who was doing their bedrooms, I cleaned their toilets. In fact, I was like a slave in the house! The work I did reminded me of slavery! I started at 7 a.m. and went to bed at midnight. And it's a job I did for three years. I used to work flawlessly (Arame, 38, Madrid).

Moraleja! A bourgeois neighbourhood! When I was hired, I was alone! I had my own cup, my own table, my own spoon, my own fork, my own knife, etc. I was not eating with the others! No way! I had my own room, my own toilet. I did not share anything with others! Every morning I was obliged to get up early before the others. I put on my uniform and my crown. As seen on TV! That is how I dressed. At first it was difficult but I eventually got used to it. (...) This is what prompted me the most to emigrate and to accept this job, yet I was eight- 
een when I came to Spain. A humiliating job! Humbling because I was washing the dog! I did his daily toilet and when he got sick, it was me who would take him to the vet (Ndeye Marieme, 42, Madrid).

Given the clash of cultures inherent to the situation of migration, for many migrant domestic workers, washing dogs or walking them is considered demeaning and humiliating. According to the Muslim religion, which is the religion and sociocultural practice of reference for a majority of them, the dog is considered an unclean animal surrounded by many taboos. For example, Islam recommends washing clothes touched by a dog before praying.

Another issue is that some Senegalese migrant women experience a deterioration of their skills as they work in Spain in low-skilled activities, while in Senegal, some of them had considerable professional work experience. Thus, with migration, some Senegalese women experience a true professional downgrading, a situation that is very frustrating for them.

Despite the migrants' awareness of their demeaning working conditions, they prefer to stick to them to make money. This is due mainly to the pressure of relatives left in Senegal. As one migrant worker observed:

If the relatives remaining in Senegal were aware of the many deprivations which we endure to make money, they would spend every penny we send them with a twinge of regret (Soukeyna, 43, Malaga).

The expectation of the family residing in Senegal is not the sole reason for pushing migrants to continue to stay in personal care work. Sometimes, they stay because it is the only activity they can perform, given their precarious legal status.

In Senegal, it was my mother or my sister who were preparing food and were undertaking the cleaning work. (...) When I arrived in Spain and I began looking for work, I was informed that I could not do certain tasks because I had no documents. I was told that the only job I could do was to look after elderly ladies. When I asked my fellow countrywomen with whom I lived about this, I was told simply and clearly that I could only work in areas that the Spanish women did not want to be in. That's it! (Fanta, 4I, Seville).

Van Nieuwenhuyze (2009: I24-I28) confirms that giving up and returning home is not really an option if one has not been at least able to pay back the money the family has invested in the trip, and preferably one should return with much more money and a 'project'; often the moral pressure from the family pushes migrants to endure their hardships. Instead of giving up, many undocumented migrants move around between neighbourhoods, cities, and even countries to look for better opportunities. Search strategies usually rely on ethnic networks, i.e. fellow Senegalese, family members and friends, and word of mouth, which in turn leads them to be pushed into the same sectors. With a larger network and language skills come more options, though as no jobs for highly educated people exist in the informal economy, human capital and skills disappear. Most migrants are stuck in the shadow economy where they are vulnerable to abuse by the employer: for regularization purposes, they need a contract, no matter how abusive.

For one of our interviewees however, having a legal status or not was not her primary concern. Unlike other migrants, what mattered to her was to find work, earn money, and support her family back in Senegal:

I had no documents but I really needed to work and earn some money to send to Senegal, the documents were not a concern for me. I did not care about documents. What mattered to me was to work, earn money, and help the family (Khardiata, 42, Almeria).

The opinion of this migrant was different from most of the other women we interviewed. For them, their irregular status constitutes a real handicap. In the absence of a valid residence permit, migrants are in an economically precarious and legally vulnerable situation. By working informally, migrants sometimes find themselves exploited by their employers who dictate the terms of the arrangement:

Some Senegalese women work without being paid! Others face all kinds of difficulties before being paid. Such cases, we see them every day. I have seen here employers whose practices do not exist anywhere else. They will pay you only half the salary and ask you to wait until next month. It is abnormal! Everyone knows it is wrong but what can you do? Without the documents, it is hard to complain. In addition, the financial crisis does not help much. If you refuse a job, the next minute others will accept it and sometimes they may even offer to be paid less (Sara, 35, Granada).

As they are unable to fulfil the legal requirements for claiming labour rights, Senegalese migrants with irregular status are forced to contend themselves with having had the chance to find work:

Without documents! I'm in an irregular situation (...) I accept all kinds of work without complaining but once I have the resident card in my hand, I will claim all my rights. Without the documents, it is difficult to say no to the boss (Rokhaya, 35, Almeria).

Pregnant migrant domestic workers with irregular status are especially vulnerable to exploitation. This is 
the case with this migrant who was at an advanced stage of pregnancy but preferred to continue working:

When you are in need, you take risks! And afterwards, one wonders how can we take such risks? I happened to work in Dallus Milagros in a big house when I was in a very advanced state of pregnancy. But hey, I had no choice! I had just arrived and I had no documents. The work was very tough, given the advanced stage of my pregnancy. At one point I wanted to stop and resume work later but as I had no documents, I did not qualify for paid maternity leave. I was working informally. I had to hide my pregnancy as much as possible to avoid being dismissed by my boss. I was doing all sorts of activities. It was very tiring, especially given the pregnancy. Finally, I was forced to stop because I had enormous problems that jeopardized my pregnancy. I think it is because of some heavy tasks I was doing that I ended up giving birth by Caesarean section (Farmata, 35 , Sevilla).

These words reveal unambiguously the low flexibility and bargaining power of migrant workers caused by their irregular status, which deprives them of the rights to enjoy good working conditions. Employers are aware of and sometimes exploit this situation:

Some employers prefer to hire someone who does not have papers to pay him a pittance or nothing at all because they know that this person will not report them (Sara, 35, Granada).

Favouring the recruitment of women with irregular status to the detriment of others is a way for some Spanish employers to have a docile labour force at low cost. Indeed, "because migrants are forced to stay in the domestic service sector due to migration policies, quota politics and the ethno-stratified labour market Spanish employers believe that a long lasting work relationship is guaranteed" (Dobner/Tappert 20I0: I8).

Senegalese migrants are aware that their irregular status does not militate in their favour because it makes them 'invisible workers' with no legal legitimacy. According to Falquet, Hirata, Kergoat, Labari, Le Feuvre and Sow (2010: I02), with few exceptions, these migrant women are mostly invisible, like the work they do, and possess an involuntary feature which is often overlooked - they exert a downwards pressure on wages in the care sector. Despite their often very specific training as care professionals, these women accept working conditions and variable hours that Spanish women try to resist.

\subsection{Working Without Being Visible: A Denial of Existence}

The invisibility of some Senegalese migrant women in Spain is thus partly explained by the fact that they work without the required papers. ${ }^{22}$ In so doing they contribute to the growth of Spain's informal economy. This situation has been further accelerated by the financial crisis in Spain in recent years. The informal economy accounts for 19.2 per cent of the official Spanish GDP (Mallet/Dinmore 20II), while Spain had an unemployment rate of 2I.2 per cent in late 20II, a record among OECD countries (OECD 20II). Not having the required documents exposes most Senegalese migrants to risky situations. Even if some of them are aware of the danger, they still prefer to follow this path to earn a living. During an interview, a migrant who has worked in domestic services in Madrid for several years argued, based on her own experience, that there is often a tacit agreement between the employer and the migrant worker on this issue:

I was working without proper documents, knowing that there are risks especially in case of accident! If this would happen, I would take care of myself by my own means. This was very clear in my mind! My boss was understanding. There was a tacit agreement between us on this point. But as I was doing my job well, she saw no reason to worry! I also worked for a lawyer and we never spoke about the documents. With some employers, you never talk about it unless they insist! (Mame Mariétou, 35, Madrid).

Particularly in Spanish households where both spouses are working, we found an increasing delegation of family responsibilities to their migrant domestic workers. These, in addition to preparing meals and cleaning the house, spend a lot of time with the children of their employers, and this in turn leads to greater closeness to them. This situation has become more visible on public transport (bus and metro) and in some school playgrounds in large cities where often women domestic workers are accompanied by

22 Van Nieuwenhuyze (2009: 98, 194) usefully points out that although we often distinguish between the formal and informal economy or jobs, this does not overlap completely with people being undocumented or not, as a migrant without papers (undocumented) can do formal work with someone else's papers, and documented migrants can do informal work. Moreover, the strict division between undocumented and regular migrant status is often blurred, partly because of the documentation strategies of migrants, partly because of informal toleration practices by the authorities. 
young Spanish children. This is part of the international transfer of social reproductive work related to the globalization of production that we observe around the world (Truong 1996).

Domestic workers come to Spain because they are able to fill this niche in the labour market. In that sense, Spanish society is also actively involved in the migration process. Thanks to the presence of migrant workers, Spanish women manage to balance household tasks and pursue leisure activities or paid employment, while the migrant workers are sometimes exposed to situations dangerous to their health, as we have seen with regard to pregnant migrant workers who prefer to hide their condition to avoid being fired. $^{23}$

Indeed, at the macro-level, Parella Rubio (2003: I87, cited in Dobner/Tappert 20I0: 2) identifies three different causes leading to an increased incorporation of migrants into domestic service in Spain: migrant networks, the migrant politics of the Spanish state, and changes in family structures and the gendered division of labour in Spain. The last includes the growth of the ageing population, falling birth rates, the integration of women into the labour market, and an increasing privatization of the social system since the I980s. Despite the growing participation of women in the Spanish labour market, traditional gender roles and the position of women as responsible carers in domestic work are maintained and reproduced in society and state policies. Domínguez-Folgueras and Castro-Martín (2008: 1518, cited in Dobner/Tappert 20IO: 3) define Spain as "still organized on the basis of a traditional model of gendered responsibilities within the family. The unpaid work of women as carers within the family remains an important pillar of social welfare, and public policies aimed at balancing family and work responsibilities remain underdeveloped." The outsourcing of domestic work is therefore usually resolved privately with the employment of migrant domestic workers, mostly women. There also is an increasing demand for domestic workers in the field of childcare due to low public financial support and limited public childcare services, with private childcare services only being affordable by a small sec-

23 Although probably only relevant for the case of regular migrants, in Spain employment tribunals (conseils de prud'hommes) continue to fight against the dismissal of pregnant domestic workers, enforcing workers' rights such as the law of work procedure, the law of reconciling personal and professional lives, and the law of effective gender equality, which all provide for the annulment of dismissals and the reinstatement of the worker. tion of society. Due to precarious employment conditions and low wages in the domestic service sector, domestic workers have thus become affordable for middle-class families who exhibit the highest demand for domestic workers in Spanish society. There is an ongoing demand for domestic workers in Spain, despite the economic crisis, and it is mostly met by female immigrants (Dobner/Tappert 20I0: 2-6).

Indeed, it is interesting to consider the impact of the financial and economic crisis. From the findings of a qualitative field study by Dobner and Tappert (20IO: IO-I3), it seems that working conditions are getting worse, especially in terms of working hours and wages. The crisis influences working conditions insofar as it leads to more dependency on the part of migrant domestic workers (with both regular and irregular status). Domestic workers who now want to change their labour sector see no chance of doing so and prefer to remain in the domestic sector. They are also more likely to accept poor and humiliating working conditions than before the crisis, for fear of not finding another job or one that is even worse than the current one. Migrant women who have not worked in the domestic work sector for a long time are being compelled to return to it. This is also the case for Spanish women, who are again increasingly seeking jobs as domestic workers. While the domestic work sector has not been hit as hard as other work sectors, the composition of the workforce is changing, as many women, female migrants as well as Spanish women, are seeking (secure) jobs, and some are returning to the domestic work sector. Labour competition thus increases, leading to a worsening of working conditions. There is a preference for migrant workers and therefore a positive discrimination towards them on the part of the employer, because of their greater dependency on the employer for work and a residence permit than is the case with Spanish domestic workers (Dobner/Tappert 20IO: I9-20; see also Solé/ Parella 2003: I24).

As indicated earlier, the demand for this kind of employment arrangement has to be set in the broader frame of an internationalized and globalized labour market, as well as taking into account international migration, in which the transnationalization and feminization of the workforce are linked processes. The demand for a flexible and cheap workforce in the labour market results in the production of identities shaped by gender, ethnicity, and class (FMP 2009: $7^{24}$, cited in Dobner/Tappert 20I0: 8).

To sum up this section: in terms of the individual migrant's life project, the process of 'becoming invisi- 
ble' and/or having irregular status could in many cases be seen as an expression of agency, with respect to how they navigate opportunities in the Spanish labour market, i.e. a rational decision though based on limited knowledge of the consequences. In fact, following Van Nieuwenhuyze (2009: 54), it is useful to think of an individual's migration project as comprising three stages in which he or she uses different strategies: 'survival strategies' apply mostly to migrants who arrive in Europe without the necessary documents or acquire irregular status, as in the group of women studied in this chapter; afterwards, many of them may try to regularize their stay, developing 'documentation strategies'; and finally, they may start to consider strategies for upward or geographical mobility. It is clear that the last strategy is increasingly being postponed due to the economic crisis, but it is worth - at least briefly - considering migrants' 'documentation strategies'.

\subsection{Seeking Access to Social Protection Rights}

Before turning to the issue of how Senegalese women migrants seek to access their rights, it is useful to briefly review the legal framework governing the domestic work sector in Spain. Since the 1980s, it has been declared a special work regime (Real Decreto $\mathrm{I} 424 / 85$ ) and does not form part of the common labour law. Rather it is defined as an "employment arrangement with exceptional characteristics". As a special work regime it contains many disadvantages concerning working conditions and social benefits, some of which have already been discussed. For example, work contracts are not obligatory; the wage is equal to the national minimum wage (624 $€$ a month), but working as a live-in can decrease the salary by up to forty-five per cent; maximum working hours are forty hours per week, but live-ins are often obliged to work more due to their continuous presence in the household. Most importantly, domestic workers do not have a right to unemployment benefits (Dobner/ Tappert 20IO: 3, footnote 7; see also Solé/Ribas/Bergalli/Parella 1998).

The work permit has to be applied for by the employer and can only be extended by him or her,

24 Federación mujeres progresistas (FMP), 2009: Tenemos la persona que necesita. Tres meses de garantía. See <http:// www.fmujeresprogresistas.org/images/contenidos/estudio\%2otrabajo\%2odomstico.pdf> (4 December 20I2). and this hinders the changing of employers and generates an extreme dependence on them, as domestic workers can lose their residence permit when changing employers or in periods of unemployment. The legal bundling of work and residence permit means that when they lose their job, or if for whatever reason they are not able to produce a job contract, the risk of not being able to extend the residence permit and therefore of being expelled is high. Live-ins in particular experience a high degree of vulnerability as they work and live in spaces that are invisible to the public, the private households of their employers, as we have seen in the examples cited above (Dobner/ Tappert 20IO: 7-8, I4).

Nevertheless, it is possible for undocumented migrants to register on the list of local residents at the municipality, provided they possess a valid passport and proof of housing/address, so that they can claim the right to health care and education for their children. However, the preconditions of registration exclude certain groups from access to health care (e.g. those who were never registered in Senegal), though a number of special health care centres focus on these groups (Van Nieuwenhuyze 2009: 133).

There is also the quite common practice of borrowing, renting, buying, or falsifying somebody else's documentation of residence and work permit to obtain a formal job using another name, though this can then jeopardize the regularization process (see Van Nieuwenhuyze 2009: I34 for examples). In any case, since, at least until recently, Spain preferred to control illegal immigration at the border rather than control undocumented migrants inside the country, undocumented migrants do not seem to have a high level of fear of repatriation. When a migrant is caught without a residence or labour permit, he or she can be administratively expelled but this is rarely translated into a physical expulsion (Van Nieuwenhuyze 2009: I38). However, even if the feeling of repression is not overwhelming, "the pending promise of 'papers' binds [migrants with irregular status] to jobs and employers, providing Spain with a vulnerable and therefore obedient labour force for the informal sector" (Van Nieuwenhuyze 2009: 156).

The 'invisibility' of Senegalese migrants in the domestic work sector is linked for some to the ignorance of their rights, the fear of losing their jobs, their unfamiliarity with the Spanish language, and their neglect of reading their work contract in the case of migrants with regular status. The latter sometimes show their employment contract to other people (spouse, friends, neighbours, etc.) to help them better under- 
stand the content. They usually prefer to use their social networks rather than private lawyers, work inspectors, social workers, etc.

Some migrant women turn to community associations when the terms of employment contracts are not respected, the tasks are not clearly defined, or the working hours are too long. This is often the case with women domestic workers with regular status who claim to be the victim of the strategies of some employers, who, citing the financial crisis, avoid giving the workers permanent contracts after nine months of work as required by law, preferring to terminate the temporary contract after a few months without any compensation. This contributes greatly to keeping Senegalese migrant women in a precarious situation. Thus Senegalese migrants are able to receive legal support or improve their living and working conditions, even if they sometimes question the effectiveness of such associations in the field of social protection. The lack of financial resources and trained personnel are a real handicap for Senegalese associations in Spain trying to meet their members' needs in terms of realizing their rights to social protection. We found that most Senegalese women migrants are aware of the social injustices which they suffer in the performance of domestic work, but their illegal status, their lack of mastery of the Spanish language, and their ignorance of the labour code prevent them from effectively addressing them.

At the national level, other authors (Danese 200I: 77; Solé/Parella 2003: I3I-I32) observe the weakened role of trade unions in representing all workers, including non-EU immigrants. While some have taken action to encourage non-discrimination and protect the rights of immigrant workers, and some have had a key role in the regularization processes, there are low levels of union membership in the domestic service, construction, and agriculture sectors, and the majority of (non-Latin American) immigrant workers have no experience of trade union practices in their country of origin. Dietz (2004: I092) shows how "the migrant populations recently appearing in Andalucía do not integrate into the local, urban or rural settings of the host-society neighbourhoods, but into the ethno-national networks which enable them to survive in the unstable continuum of legal and illegal economic activities".

\subsection{Conclusions}

By sending women to Spain for the picking of strawberries as part of a temporary migration scheme, the Spanish and Senegalese governments hoped to offer them a job in Europe as well as finding cheap labour for agricultural enterprises. Due to harsh working conditions and low wages which were misaligned to their profiles and expectations, some Senegalese women preferred to abandon the fields for other Spanish cities where they joined other Senegalese working in domestic service. Without regular residence permits, some of these women found themselves in precarious situations reducing their statutory and contractual rights. They encountered abuses such as overtime being rarely paid, extremely variable working hours, and sometimes even verbal, physical, and psychological violence. Domestic workers with legal status also face difficulties such as the downgrading of skills, isolation, and not being allowed to change employers or become pregnant for a certain number of years.

From the findings presented here, we can draw conclusions and policy implications for both temporary (agricultural) work schemes and for the situation of female migrant domestic workers in Spain, all of which revolve around labour market issues, questions of regulation, and unforeseen outcomes in terms of social (in)justice. In documenting the process of transition from one sector to another, we have also seen that while choices are limited as a result of the restrictive migration regimes and economic adverse conditions, agency remains important (Van Nieuwenhuyze 2009: 195).

The findings on the temporary agricultural work scheme show that policies which fail to understand the temporary migrant workers' lives - that many are well educated, that they are not merely pairs of harvesting hands, that they have networks in Spain, that allocation of places in temporary migration schemes will in Senegal inevitably be partly on the basis of patronage - can never obtain their objectives.

As for the findings on migrant domestic workers presented here, they illustrate very clearly the special characteristics found in the domestic work sector, namely "the intimate character of the social sphere where the work is performed; the social construction of this work as a female gendered area; the special relationship between employer and employee which is highly emotional, personalized and characterized by mutual dependency" (Lutz 2008: I, cited in Dobner/ Tappert 20IO: 8; see also Gutiérrez-Rodríguez 20IO). 
In terms of policy implications, legal immigration of the unskilled is arguably desirable, along with affordable social protection for these workers. Temporary migration schemes are seen as a good match between the needs of some labour markets, the pressure for migration, the fear of a brain drain, and the potential of return migration. Theoretically, if the system is transparent, predictable, and rights-based, it could be a realistic and cost-effective policy option (BaldwinEdwards 2004; Ghosh 2000; cited in Van Nieuwenhuyze 2009: 198). In practice, to address some of the shortcomings presented here it is necessary to build on the institutional capacities of the governments of countries of origin for the management of migration flows, increasing the number of diplomatic representations, consular offices, and jointly-run employment services, in order to streamline the processes of recruitment, selection, and return of foreign workers (EMN 20IO: 55; see also the lessons learnt from the management of seasonal Moroccan migration around Huelva as found in González Enríquez 20II). Other studies have also shown that the need for well-prepared workers includes training on contracts, knowledge of legal processes and resources in host country, including basic rights, some job skills training, cultural awareness, and adequate language abilities (Morgan/ Nolan 20II: I7).

However, if foreign workers do not wish to return home, the creation of a population of undocumented immigrants may be almost inevitable (Van Nieuwenhuyze 2009: 198).

This is particularly the case for Spain, which has not yet developed a legal framework to encourage the temporary or circular migration of documented foreign nationals living in Spain to and from their countries of origin. Although any foreign worker with a valid work and residence permit may enter and leave Spain, the requirement to fulfil the necessary residence and (uninterrupted) employment criteria for maintaining or renewing these permits restricts circular and temporary mobility from Spain to countries of origin. Only in the case of migrants with long-term residence permits (obtained after residence for a continuous five-year period) are there no practical restrictions on movement between Spain and countries of origin (EMN 20IO: 32).

It is therefore not surprising that Newland/Agunias/Dovelyn/Terrazas (2008: 22) conclude that "many of the conditions of migration programs for the less skilled, intended to 'enforce' circularity, seem to have the opposite effect of encouraging irregular migration: very short contract periods, non-renewable visas, visas tied to particular employers, and no flexibility to switch to other admission categories are all conditions that create incentives for migrants to leave the programs and move into irregular status". They therefore suggest that "incentives for circulation, like pension portability or an 'earned' right to remain permanently, may be more effective than enforcement measures" (2008: 23).

It seems that the Spanish government is making progress along these lines, as its Ministry of Labour and Immigration produced the Plan Estratégico de Ciudadanía e Integración (Strategic Plan for Citizenship and Integration) for 2007-20I0, which was approved by the Spanish Government in 2007. Among other measures, the Plan includes actions to foster the inclusion of seasonal workers and encourage their return with skills and resources enabling them to act as development agents in their places of origin. This is sought through active employment policies in countries of origin and voluntary return programmes. ${ }^{25}$ The Plan also seeks to encourage the signing of bilateral social security agreements with several countries (as of 20IO, not yet with Senegal) for the recognition of pension rights and other benefits, which could be a stimulus for temporary and circular mobility in the medium and long term (EMN 20IO: 22-23).

Since bilateral treaties still mostly do not take into account the views of the migrants themselves (Wabgou 2008: I48), such policy changes would help migrants to fulfil their life projects. As Riccio (200I: 590) observes, most Senegalese migrants in Europe would prefer to conduct truly transnational lives, living part of the year here and the other part there, and making the best of both worlds. However, "far from being in a post-national era [...], transnational organization still needs to negotiate with nation and local state regulatory and sometimes exclusionary practices as well as with the representations of immigrants held in the migration context" (Riccio 200I: 590, citing Grillo/Riccio/Salih 2000). ${ }^{26}$

25 See also the (limited) training activities organized by the ILO for Senegalese migrants, targeting among others the return and reinsertion of migrants (see <http://bitmigrant.wordpress.com/> (I9 November 20I2). On return to Senegal within government-led initiatives and their misalignment with migrant perspectives, see Sinatti (20I2).

26 See also Sinatti (2011) for the argument that Senegalese migrants' self-perception of successful return is still largely associated with permanent return. 


\section{References}

Agrela Romero, Belén; Gil Araujo, Sandra, 2005: "Constructing Otherness. The management of migration and diversity in the Spanish context", in: Migration: A European Journal of International Migration and Ethnic Relations, 43-45: 9-33.

Apap, Joanna, 200I: "Extending Citizenship Rights to Third Country Nationals. The Correlation Between Migration and Integration: A Sample from South Europe", in: CEPS Policy Brief, I75 (October); at: <http:// www.ceps.eu/book/extending-citizenship-rights-thirdcountry-nationals-correlation-between-migration-andintegrat> (3 September 20I2).

Babou, Cheikh Anta, 2008: "Migration and Cultural Change: Money, 'Caste', Gender, and Social Status among Senegalese Female Hair Braiders in the United States", in: Africa Today, 55,2 (Winter): 3-22.

Baldwin-Edwards, Martin, 2004: "Immigrants and the Welfare State in Europe", in: Massey, Douglas S.; Taylor, J. Edward (Eds.): International Migration: Prospects and Policies in a Global Market (Oxford: Oxford University Press): 3I8-334.

Blanchard, Melissa (20I2): "Regard communautaire sur le parcours social et la sexualité des femmes sénégalaises 'solitaires' à Marseille", in: SociologieS (Dossiers, Amours Transi(t)s. Transactions sexuelles au prisme de la migration), published on-line on 27 January 20I2, at: <http://sociologies.revues.org/3863> (9 August 20I2).

Bocquier, Philippe, I992: "L'insertion et la mobilité professionnelles à Dakar” (PhD dissertation, Université René Descartes, Paris V).

Burnett, Victoria, 2007: "To Curb Illegal Migration, Spain Offers a Legal Route", in: The New York Times (II August 2007); at: <http://www.nytimes.com/2007/08/ II/world/europe/IIspain.html> (9 August 20I2).

Castles, Stephen, 2002: "Migration and Community Formation under Conditions of Globalization", in: International Migration Review, 36,4 (December): II43-II68.

Corkill, David, 200I: "Economic migrants and the labour market in Spain and Portugal", in: Ethnic and Racial Studies, 24,5: 828-844.

Coulibaly-Tandian, Oumoul Khaïy, 2008: "Socio-anthropologie des mobilités sénégalaises à Toulouse et Barcelone et leurs influences au Sénégal. Diversité des pratiques, Organisation en réseaux, Place des NTIC et Analyse de genre" (PhD dissertation, Université de Toulouse and Université Gaston Berger de Saint-Louis).

Danese, Gaia, 200I: "Participation beyond citizenship: migrants' associations in Italy and Spain", in: Patterns of Prejudice, 35,I: 69-89.

Dietz, Gunther, 2004: "Frontier Hybridization or Culture Clash? Trans-national migrant communities and subnational identity politics in Andalusia, Spain”, in: Journal of Ethnic and Migration Studies, 30,6: I087-III2.

Dobner, Marianne; Tappert, Simone, 20I0: "Female migrant domestic workers and their Spanish employers in times of crisis. A comparative analysis of consequences for women on both sides of the coin", Paper for the SGIR $7^{\text {th }}$ Pan-European International Relations Conference, Stockholm, Sweden, 9-II September.

Domínguez-Folgueras, Marta; Castro-Martín, Teresa, 2008: "Women's changing socioeconomic position and union formation in Spain and Portugal", in: Demographic Research, 19,4I (August): 15I3-I550.

Domingo, Andreu; Kaplan, Adriana; Gómez Gil, Carlos, 2000: Easy Scapegoats: Sans-Papiers Immigrants in Europe: Report on Spain (Barcelona: Centre d'Estudis Demogràfics).

EMN (European Migration Network), 20Iо: Temporary and Circular Migration: Empirical Evidence, Current Policy Practice and Future Options in Spain (December); at: <http://extranjeros.empleo.gob.es/es/RedEuropeaMigraciones/Estudios_monograficos/EMN-ENCircular-Migration.pdf> (9 August 20I2).

Fall, Papa Demba, 1998: "Stratégies et implications fonctionnelles de la migration sénégalaise vers l'Italie”, in: Migrations Société, Io,60: 7-33.

Falquet, Jules; Hirata, Helena; Kergoat, Danièle; Labari, Brahim; Le Feuvre, Nicky; Sow, Fatou, 20Io: Le sexe de la mondialisation. Genre, classe, race et nouvelle division du travail (Paris: Presses de Sciences Po).

FMP (Federación mujeres progresistas); at: 2009: Tenemos la persona que necesita. Tres meses de garantía. <http:// www.fmujeresprogresistas.org/images/contenidos/ estudio\%20trabajo\%2odomstico.pdf> (4 December 20I2).

Freeman, Gary P., I995: "Modes of Immigration Politics in Liberal Democratic States", in: International Migration Review, 29,4 (Winter): 88I-902.

García-Cano, Ana Maria, 2002: "Limmigration non communautaire féminine vers l'Espagne" in: Migrance 2I, deuxième trimestre: II6-I3I; at: <http://www.generiques.org/ images/pdf/Migrance_2Ifra.pdf > (3 September 20I2).

Garreta Bochaca, Jordi, 200I: "Les immigrés africains sur le marché du travail espagnol", in: Migrations Société, I3,77: 7-I7.

Ghosh, Bimal, 2000: "New International Regime for Orderly Movements of People: What will it Look Like?", in: Ghosh, Bimal (Ed.): Managing Migration: Time for a New International Regime? (Oxford: Oxford University Press): 6-26.

González Enríquez, Carmen, 20II: “Temporary Migration between Morocco and Spain”, in: Real Instituto Elcano ARI, III/20II, 2I/07/20II; at: <http://www.realinstitutoelcano.org/wps/wcm/connect/7962228047aagcd88I2 6d9076e8e26e4/ARIIII-20II_Temporary_Migration_ Morocco_Spain.pdf?MOD=AJPERES\&CACHEID $=7962$ 228047aa9cd88I26d9076e8e26e4> (3 September 20I2).

González-Ferrer, Amparo; Graus Elisabeth, 20I2: "Migrantes senegaleses en Francia, Italia y España: primeros resultados de la encuesta MAFE-Senegal en Europa", in: Real Instituto Elcano ARI, 8/20I2, 02/O2/20I2; at: < http:// www.realinstitutoelcano.org/wps/wcm/connect/49ob5 e004a047dodaeo2bf39d72a98ae/ARI8-20I2_Gonzalez- 
Ferrer_Kraus_migrantes_senegal_Espana_Italia_Francia _MAFE.pdf?MOD=AJPERES\&CACHEID $=490$ b5eo०4 a047dodaeo2bf39d72a98ae> (3 September 20I2).

Grillo, Ralph D.; Riccio, Bruno; Salih, Ruba, 2000: "Here or There? Contrasting Experiences of Transnationalism: Moroccans and Senegalese in Italy", in: CDE Working Paper (Brighton: University of Sussex).

Gutiérrez-Rodríguez, Encarnación, 2010: Migration, Domestic Work and Affect: A Decolonial Approach on Value and the Feminization of Labor (New York Abingdon: Routledge).

Hoggart, Keith; Mendoza, Cristóbal, I999: "African Immigrant Workers in Spanish Agriculture”, in: Sociologia Ruralis, 39,4 (October): 538-562.

Kaplan Marcusán, Adriana, 2005: "From Senegambia to Spain: Migration process and social integration”, in: Migration: A European Journal of International Migration and Ethnic Relations, 43-45: 52-65.

Kohnert, Dirk, 2007: "African Migration to Europe: Obscured Responsibilities and Common Misconceptions" in: GIGA Working Papers, 49 (May).

Lessault, David; Beauchemin, Cris, 2009: "Migration from sub-Saharan Africa to Europe: still a limited trend", in: Population \& Societies, 452 (January).

Lessault, David; Mezger, Cora, 20IO: "La migration internationale sénégalaise. Des discours public à la visibilité statistique”, in: MAFE Working Paper, 5 (April).

Lutz, Helma, 2008: "Introduction", in: Lutz, Helma (Ed.): Migration and Domestic Work: A European Perspective on a Global Theme (Aldershot: Ashgate): I-I2.

Lutz, Helma, 20II: The New Maids: Transnational Women and the Care Economy (London and New York: Zed Books).

Mallet, Victor; Dinmore, Guy, 20II: "Europe: Hidden economy", Financial Times (8 June 20II); at: < http:// www.ft.com/intl/cms/s/o/efc35Ioe-92I4-IIeo-geoo-ooI 44feab49a.html\#axzz2CgI7PMXu> (I9 November 20I2).

Mendoza, Cristóbal, 200I: "The role of the state in influencing African labour outcomes in Spain and Portugal", in: Geoforum, 32: 167-180.

Morgan, Guy; Nolan, Chris, 20II: Step Up: Improving the Recruitment of Migrant Workers in Indonesia (BSRMigration Linkages); at: <http://www.bsr.org/reports/ Improving_Migrant_Worker_Recruitment_in_Indonesia. pdf> (9 August 20I2).

Newland, Kathleen; Agunias, Dovelyn Rannveig; Terrazas, Aaron, 2008: "Learning by Doing: Experiences of Circular Migration", in: Migration Policy Institute Insight (September).

OECD (Organisation for Economic Co-operation and Development), 2005: African Economic Outlook: Senegal (Paris: OECD).

OECD (Organisation for Economic Co-operation and Development), 20II: OECD Perspectives: Spain. Policies for a sustainable recovery, October; at: 〈http://www. oecd.org/spain/44686629.pdf> (I9 November 20I2).
Parella Rubio, Sònia, 2003: Mujer, inmigrante, trabajadora: la triple discriminación (Barcelona: Anthropos).

Riccio, Bruno, 200I: "From 'ethnic group' to 'transnational community'? Senegalese migrants' ambivalent experiences and multiple trajectories", in: Journal of Ethnic and Migration Studies, 27,4: 583-599.

Robin, Nelly, 1996: "La Multipolarisation de la Migration Sénégalaise”, in: Ma Mung, Emmanuel (Ed.): Mobilités et investissements des émigrés: Maroc, Tunisie, Turquie, Sénégal (Paris: L'Harmattan): 48-64.

Rosander, Eva Evers, 2005: "Cosmopolites et locales: femmes sénégalaises en voyage” in: Afrique \& histoire, 4,2: IO3-I22.

Sassen, Saskia, 2000: "Mais pourquoi émigrent-ils?", Le Monde Diplomatique (November); at: <http://www. monde-diplomatique.fr/2000/II/SASSEN/I4478> (3 September 20I2).

Sinatti, Giulia, 20II: “Mobile Transmigrants' or 'Unsettled Returnees'? Myth of Return and Permanent Resettlement among Senegalese Migrants" in: Population, Space and Place, I7: 153-166.

Sinatti, Giulia, 20I2: "Return Migration as a Win-Win-Win Scenario? Visions of Return among Senegalese Migrants, the State of Origin and Receiving Countries", Paper for the workshop Return migration and transnationalism: alternatives or complements?, Oslo, Norway, 4-5 September.

Siregar, Lukman Hakim, 20Iо: "Bilateral Agreements on Migrant Workers: Developing a Legal Instrument for Protecting Indonesian Citizens Abroad", in: Journal Diplomasi, 2/r: I69-186; at: <http://isjd.pdii.lipi.go.id/ admin/jurnal/2IIOI69I86_2085-6075.pdf> (I9 November 20I2).

Solé, Carlota, I994: La mujer inmigrante (Madrid: Ministerio de Asuntos Sociales, Instituto de la Mujer)

Solé, Carlota; Ribas, Natalia; Bergalli, Valeria; Parella, Sònia, I998: "Irregular employment amongst migrants in Spanish cities", in: Journal of Ethnic and Migration Studies, 24,2: 333-346

Solé, Carlota; Parella, Sònia, 2003: "The labour market and racial discrimination in Spain”, in: Journal of Ethnic and Migration Studies, 29,I: I2I-I4O.

Sow, Fatou, 2006: "Genre, droits humains et migrations en Afrique subsaharienne", Paper for the International Conference on Migration and Development, Rome, 8Io June; at: <http://www.cespi.it/CESPI-SID/Afrique_ subsaharienne.pdf> (3 September 20I2).

Tall, Serigne Mansour, 2008: "La migration internationale sénégalaise: des recrutements de main-d'œuvre aux pirogues”, in: Diop, Momar-Coumba (Ed.): Le Sénégal des migrations. Mobilités, identités et societies (Dakar: CREPOS-KARTHALA-ONU HABITAT): 37-67.

Tall, Serigne Mansour; Tandian, Aly, 20IO: "Entre regroupement familial et migrations autonomes des femmes sénégalaises. Quelle analyse de genre des migrations sénégalaises?", in: CARIM Notes d'analyse et de synthèse, 2010/69; at: <http://cadmus.eui.eu/bitstream/ 
handle/I8I4/I5288/

CARIM_ASN_20IO_69.pdf?sequence=I $>$ (3 September 2OI2).

Tandian, Aly, 2008: "Des migrants sénégalais qualifiés en Italie: entre regrets et resignation" in: Diop, MomarCoumba (Ed.): Le Sénégal des migrations. Mobilités, identités et societies (Dakar: CREPOS-KARTHALAONU HABITAT): $365-388$.

Tandian, Aly; Coulibaly, Oumoul Khairy; Sow, Papa; Tall, Serigne Mansour; Wade, Cheikh Tidiane; Dioh, Adrien; Dime, Mamadou dit Ndongo; Ba, Amédoune; Badji, Mariama; Gueye, Cina; Mbaye, Thierno; Tandia, Aboubakr; Diallo, Sellou; Diagne, Moussa; Mbengue, Mamadou Abdoulay; Vasquez, José Luis; Seron, Gema; Kebe, Ndongo; Sane, Mamadou Bonaventure; Thiakh, Ababacar; Thioye, Alassane Ibrahima; Gueye, Cheikh; Niang, Ousseynou; and Ciss, Mareme (20II): "Protection sociale des migrantes Sénégalaises évoluant dans les activités agricoles et les services aux particuliers en Espagne: Rapport de recherche”, Le Groupe d'Etudes et de Recherches sur les Migrations (GERM) \& Faits de Sociétés, Université Gaston Berger de Saint-Louis, Senegal (Mimeo).
Truong, Than Dam, 1996: "Gender, International Migration and Social Reproduction: Implications for Theory, Policy, Research and Networking", in: Asian and Pacific Migration Journal, 5, I: 27-5I.

UNESCO (United Nations Educational, Scientific and Cultural Organization), 2008: People on the Move. Handbook on Selected Terms and Concepts. Version I.o; at: <http://unesdoc.unesco.org/images/oor6/oor636/ı6 362Ie. pdf> (3 September 2012).

Van Nieuwenhuyze, Inge, 2009: Getting by in Europe's Urban Labour Markets: Senegambian Migrants' Strategies for Survival, Documentation and Mobility (Amsterdam: IMISCOE Dissertations - Amsterdam University Press).

Wabgou, Maguemati, 2008: "Governance of migration in Senegal: The role of government in formulating migration policies", in: Adepoju, Aderanti; van Naerssen, Ton; Zoomers, Annelies (Eds.): International migration and national development in sub-Saharan Africa: Viewpoints and policy initiatives in the countries of origin (Leiden: Brill): I4I-I60.

Open Access. This chapter is distributed under the terms of the Creative Commons Attribution Non-commercial License, which permits any noncommercial use, distribution, and reproduction in any medium, provided the original author(s) and source are credited. 